\title{
Enhance Food Security through Fruit and Vegetable Preservation
}

\author{
Poonam Kundu*, Kanta Sabarwal and Sube Singh \\ Department of Extension Education and Com. Mgt. College of Home Science, \\ CCSHAU, Hisar, Haryana, India
}

\begin{tabular}{|l|}
\hline K e y w o r d s \\
Empowerment, \\
Training, Preservation, \\
Processing, Perishable \\
\hline Article Info \\
\hline $\begin{array}{l}\text { Accepted: } \\
\text { 26 March } 2018 \\
\text { Available Online: } \\
\text { 10 April } 2018\end{array}$ \\
\hline
\end{tabular}

A B S T R A C T

The present study was conducted in Sirsa district on fifty rural women beneficiaries to whom ten days rigorous training was given on food and preservation. Results highlighted the facts that 64.0 percent beneficiaries were educated upto secondary level and only 12 percent were graduated and belonged to agricultural community. Most of the women were doing little bit of pickle work like lemon and chilly pickle. But they were unaware about other preservation procedures like formation of squashes, chutneys, murrabha, etc. They did not have enough knowledge about precautions to be taken while doing preservation activities. Beside this they were unaware about the important chemicals used in preservation like sodium benzoate and potassium meta-bisulphate. The maximum knowledge observed was in how to make tomato chutney $(92.0 \%)$ followed by anvola pickle, mixed pickle, squash/sherbets and jam making. The study also highlighted the facts that today rural women want to stand up on their own feet but they lack self-confidence and family support. Therefore more efforts are to be directed to persuade rural women to start their own cottage industry on preservation.

\section{Introduction}

India's diverse climate ensures availability of all varieties of fresh fruits and vegetables. It ranks second in fruits and vegetables production in the world, after China. As per National Horticulture Database published by National Horticulture Board, during 2014-15 India produced 86.602 million metric tonnes of fruits and 169.478 million metric tonnes of vegetables. But unfortunately due to skilled manpower deficiency, poor cold storage facilities, inefficient post-harvest management and minimal technological interventions, India is the second largest producer contributes only $1 \%$ of the global market of the fruit processing industry. In India, the wastage of fresh fruit, produce has been estimated to be of a very high order, i.e. around $30-35 \%$ of the total production during harvest, storage, grading, transport, packaging and distribution because of the challenges involved in the industry. It is evident that there is considerable scope for expansion of processing of fruits and vegetables. Development of processing industry on modern, scientific lines would produce a variety of benefits. Hence to avoid the glut in the market, they can be processed, preserved and can be enjoyed in off season. Varity of bi-products can be prepared like jam, jelly, pickles, marmalade, squashes, etc, frozen, dehydrated and dried vegetables. This 
shows one can easily take up food preservation as an entrepreneurial activity and can run her own enterprise keeping these facts in mind a study was conducted at KVK Sirsa of Haryana State in order to motivate women to stand on their own feet and contribute towards family income.

\section{Materials and Methods}

The study was carried out on the campus of KVK Sirsa of Haryana State under RKVY project. Two rigorous trainings of 10 days each were conducted for the two selected group of rural women. The selected group comprise of 25 rural women each, selected from 19 different villages of Sirsa district. In each training 12 different products namely green chilli pickle, red chilli pickle, lemon pickle, mix pickle, mushroom pickle, anvola pickle, ginger pickle, tomato chutney, tomato sauce, sharbat, anvola murabha, jams, and gulukand were demonstrated. Despite from this, the rural women were also equipped with the knowledge of how to grow and consume mushroom at their homes, how to dry vegetable at home, how to freeze fruits and vegetable, etc. The Practical sessions were carried out with the help of method and result demonstrations. Frequency and percentage were used to draw the results and conclusions.

\section{Results and Discussion}

The data presented in Table 1 shows the socioeconomic profile of the trainees of fruit and vegetable preservation. Maximum number of trainees i.e. 52.00 percent falls between the 25-35 years of age group whereas 36.00 percent of trainees' fall in the age group between 15-25 years. Majority of trainees i.e. 64.00 percent were educated up to secondary level followed by 24.00 percent of trainees who were educated up to primary level and 12.00 percent of the trainees had done graduation. The data further indicate that
70.00 percent of the trainees were from general category whereas 30.00 percent of the trainees were from SC/Backward class. Fifty percent of the trainees were earning their livelihood through agriculture, 30.00 percent were working as agricultural labour, 12.00 percent of the trainees were engaged in service and only 8.00 percent were working as shopkeepers. Maximum number of trainees i.e. 56.00 percent belong to nuclear family whereas 44.00 percent of the trainees were from joint family system.

The data Table 2 shows the common procedures of preservation. The post analyses of the data tells us that the maximum knowledge gain was observed in blanching and chutneys (96,00 percent) followed by 92.00 percent in jam, 84.00 percent in squashes/sherbet, 76.00 percent in murabha, 64.00 percent in drying and 60.00 percent in pickling. The knowledge gain in drying and pickling was low because ladies are already doing drying and pickling at their homes.

The data depicted in Table 3 shows the knowledge gain of different procedures of preservative products. Maximum gain in knowledge i.e. 96.00 percent was observed in tomato chutney followed by 92.00 percent in anvola pickle, 88.00 percent was observed in mixed pickle, squash/sherbets and jam making.

The data further reveals 84.00 percent knowledge gain in ginger pickle, tomato sauce, and anvola murabah whereas 76.00 percent knowledge gain was observed in gulukand and mushroom pickle followed by 64.00 percent in lemon pickle and 56.00 percent in chilli pickle. The critical analyses of the data reveals that the percentage knowledge gain score was low in activities which they are already doing at home. Results are inconsonance with Yadav and Varma (2014) and Batra (2011). 
Table.1 General Information of the respondents

\begin{tabular}{|c|c|c|c|}
\hline S. No & Parameters & Frequency & Percentage \\
\hline \multirow[t]{4}{*}{1} & Age & & \\
\hline & $15--25$ & 18 & $36.0 \%$ \\
\hline & $25--35$ & 26 & $52.0 \%$ \\
\hline & $35--45$ & 06 & $12.0 \%$ \\
\hline \multirow[t]{6}{*}{2} & Education & & \\
\hline & Illiterate & - & - \\
\hline & Primary & 12 & $24.0 \%$ \\
\hline & Secondary & 32 & $64.0 \%$ \\
\hline & Graduation & 06 & $12.0 \%$ \\
\hline & Post Graduation & - & - \\
\hline \multirow[t]{3}{*}{3} & Cast & & \\
\hline & General & 35 & $70 \%$ \\
\hline & SC/Backward & 15 & $30 \%$ \\
\hline \multirow[t]{5}{*}{4} & Source of family earning & & \\
\hline & Agricultural Laborer & 15 & $30.0 \%$ \\
\hline & Agriculture & 25 & $50.0 \%$ \\
\hline & Shopkeeper & 04 & $08.0 \%$ \\
\hline & Service & 06 & $12.0 \%$ \\
\hline \multirow[t]{3}{*}{5} & Type of Family & & \\
\hline & Nuclear & 28 & $56.0 \%$ \\
\hline & Joint & 22 & $44.0 \%$ \\
\hline
\end{tabular}

Table.2 What are the common procedures of preservation?

\begin{tabular}{|l|l|c|c|c|}
\hline $\begin{array}{l}\text { S. } \\
\text { No. }\end{array}$ & Procedures & $\begin{array}{l}\text { Pre-Score and } \\
\text { Percentage }\end{array}$ & $\begin{array}{l}\text { Post Score and } \\
\text { Percentage }\end{array}$ & $\begin{array}{l}\text { Knowledge gap } \\
\text { and Percentage }\end{array}$ \\
\hline $\mathbf{1}$ & Blanching & -- & $48(96.0 \%)$ & $48(96.0 \%)$ \\
\hline $\mathbf{2}$ & Drying & $18(36.0 \%)$ & $50(100 \%)$ & $32(64.0 \%)$ \\
\hline $\mathbf{3}$ & Pickling & $20(40.0 \%)$ & $50(100 \%)$ & $30(60.0 \%)$ \\
\hline $\mathbf{4}$ & Jam & -- & $46(92.0 \%)$ & $46(92.0 \%)$ \\
\hline $\mathbf{5}$ & Squash & -- & $42(84.0 \%)$ & $42(84.0 \%)$ \\
\hline $\mathbf{6}$ & Chutnies & -- & $48(96.0 \%)$ & $48(96.0 \%)$ \\
\hline 7 & Murabha & -- & $38(76.0 \%)$ & $38(76.0 \%)$ \\
\hline
\end{tabular}

(Multiple response table) 
Table.3 Knowledge gain of different procedures of preservative products

\begin{tabular}{|c|c|c|c|c|}
\hline S. No. & Products & $\begin{array}{l}\text { Pre-Score and } \\
\text { Percentage }\end{array}$ & $\begin{array}{l}\text { Post Score and } \\
\text { Percentage }\end{array}$ & $\begin{array}{l}\text { Knowledge gap } \\
\text { and Percentage }\end{array}$ \\
\hline 1 & Chilli Pickle & $22(44.0 \%)$ & $50(100 \%)$ & $28(56.0 \%)$ \\
\hline 2 & Lemon Pickle & $18(36.0 \%)$ & $50(100 \%)$ & $32(64.0 \%)$ \\
\hline 3 & Anvola pickle & -- & $46(92.0 \%)$ & $46(92.0 \%)$ \\
\hline 4 & Ginger pickle & -- & $42(84.0 \%)$ & $42(84.0 \%)$ \\
\hline 5 & Mushroom pickle & -- & $38(76.0 \%)$ & $38(76.0 \%)$ \\
\hline 6 & Mixed Pickle & $06(12.0)$ & $50(100 \%)$ & $44(88.0 \%)$ \\
\hline 7 & Tomato chutney & -- & $48(96.6 \%)$ & $48(96.0 \%)$ \\
\hline 8 & Tomato Sauce & -- & $42(84.0 \%)$ & $42(84.0 \%)$ \\
\hline 9 & Squash / Sherbets & -- & $44(88.0 \%)$ & $44(88.0 \%)$ \\
\hline 10 & Gulukand & -- & $38(76.0 \%)$ & $38(76.0 \%)$ \\
\hline 11 & Jam making & -- & $44(88.0 \%)$ & $44(88.0 \%)$ \\
\hline 12 & Anvolamurabha & -- & $42(84.0 \%)$ & $42(84.0 \%)$ \\
\hline
\end{tabular}

(Multiple Response Table)

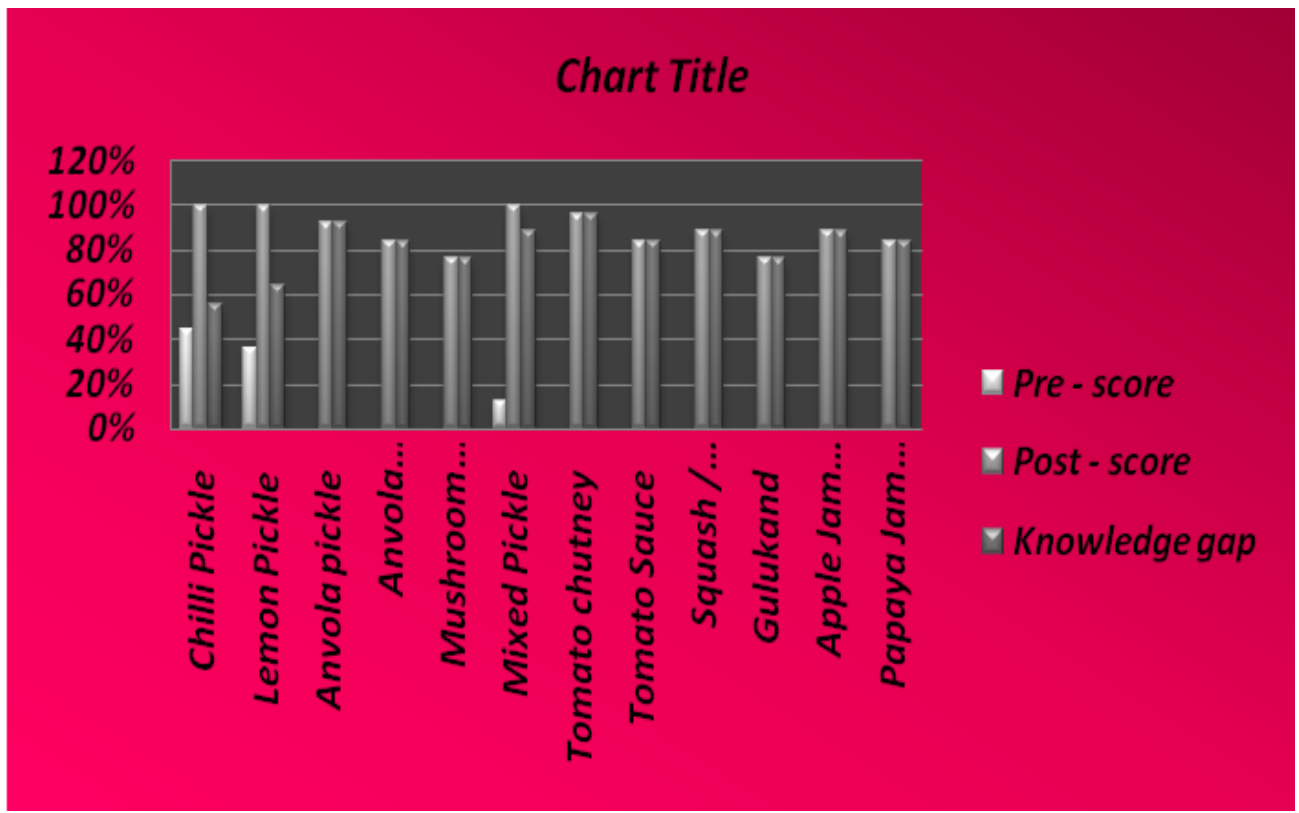


Table.4 Preventive measure to be taken during preservation

\begin{tabular}{|l|l|c|c|c|}
\hline $\begin{array}{l}\text { S. } \\
\text { No. }\end{array}$ & $\begin{array}{l}\text { Precautions } \\
\text { Percentage }\end{array}$ & $\begin{array}{l}\text { Post } \\
\text { and } \\
\text { Percentage }\end{array}$ & $\begin{array}{l}\text { Score } \\
\text { gap Percentage }\end{array}$ \\
\hline $\mathbf{1}$ & $\begin{array}{l}\text { Availability of fruits/ vegetables in } \\
\text { abundance. }\end{array}$ & $06(12.0 \%)$ & $50(100 \%)$ & $44(88.0 \%)$ \\
\hline $\mathbf{2}$ & $\begin{array}{l}\text { Selection of fruits/ vegetables } \\
\text { Counter should be neat and clean }\end{array}$ & $10(20.0 \%)$ & $50(100 \%)$ & $40(80.0 \%)$ \\
\hline $\mathbf{3}$ & \begin{tabular}{l} 
Wash your hands \\
\hline $\mathbf{5}$
\end{tabular} & -- & $50(100 \%)$ & $50(100 \%)$ \\
\hline $\mathbf{6}$ & $\begin{array}{l}\text { Use of apron } \\
\text { Products should be kept in clean } \\
\text { and dry glass jars/bottles or in } \\
\text { earthen pots. }\end{array}$ & $-06(12.0 \%)$ & $50(100 \%)$ & $44(88.0 \%)$ \\
\hline
\end{tabular}

(Multiple Response Table)

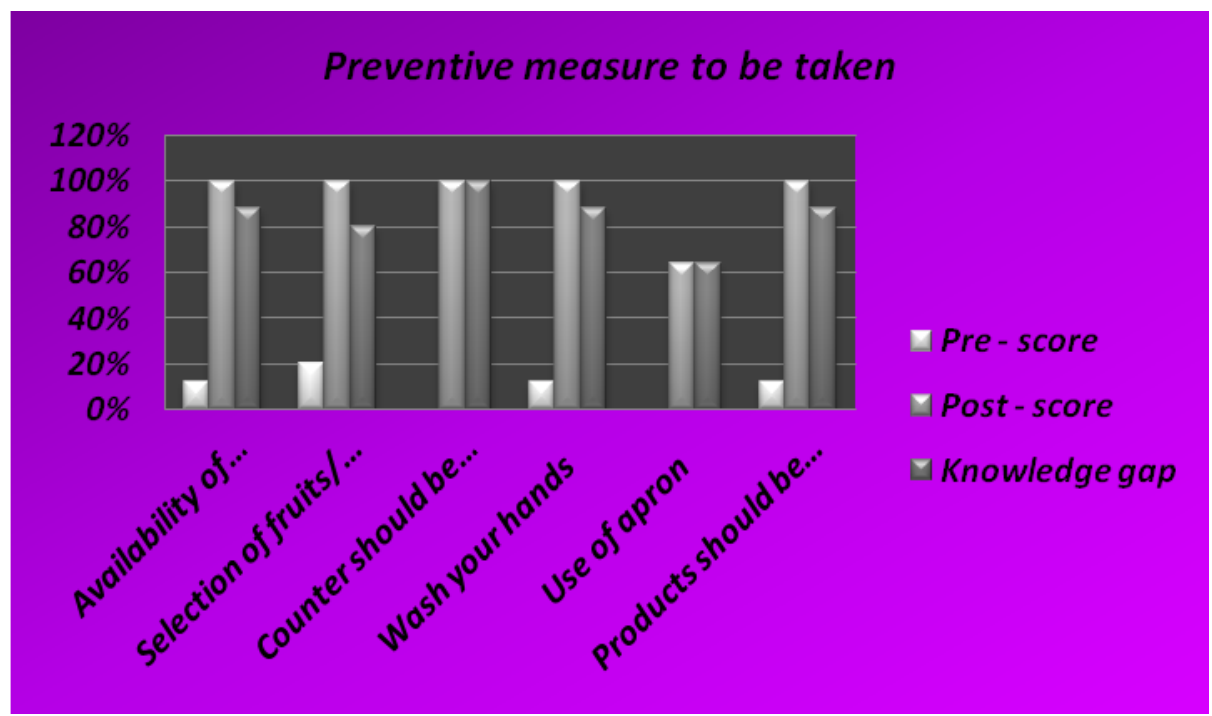

Table.5 What are the common preservatives used during preservation?

\begin{tabular}{|l|l|r|r|r|}
\hline $\begin{array}{l}\text { S. } \\
\text { No. }\end{array}$ & Preservatives & $\begin{array}{l}\text { Pre-score and } \\
\text { percentage }\end{array}$ & $\begin{array}{l}\text { Post score and } \\
\text { percentage }\end{array}$ & $\begin{array}{l}\text { Knowledge gap } \\
\text { and percentage }\end{array}$ \\
\hline $\mathbf{1}$ & Sugar & $12(24.0 \%)$ & $50(100 \%)$ & $38(76.0 \%)$ \\
\hline $\mathbf{2}$ & Salt & $38(76.0 \%)$ & $50(100 \%)$ & $12(24.0 \%)$ \\
\hline $\mathbf{3}$ & Vinegar & $08(16.0 \%)$ & $42(84.0 \%)$ & $34(68.0 \%)$ \\
\hline $\mathbf{4}$ & Sodium Benzoate & -- & $38(76.0 \%)$ & $36(72.0 \%)$ \\
\hline 5 & $\begin{array}{l}\text { Potassium/Sodium } \\
\text { Meta-bisulphate }\end{array}$ & -- & $38(76.0 \%)$ & $38(76.0 \%)$ \\
\hline
\end{tabular}

(Multiple Response Table) 
Table.6 What motive do you have behind this training?

\begin{tabular}{|l|l|c|c|}
\hline S. No. & Statements & Frequency & Percentage \\
\hline $\mathbf{1}$ & To learn about food preservation & 46 & $92.0 \%$ \\
\hline $\mathbf{2}$ & To utilize your time in a productive work & 34 & $68.0 \%$ \\
\hline $\mathbf{3}$ & To get the incentive & 12 & $24.0 \%$ \\
\hline $\mathbf{4}$ & To get the certificate & 36 & $72.0 \%$ \\
\hline $\mathbf{5}$ & To do preservation at home & 38 & $76.0 \%$ \\
\hline 6 & To start your own venture & 08 & $16.0 \%$ \\
\hline
\end{tabular}

(Multiple Response Table)

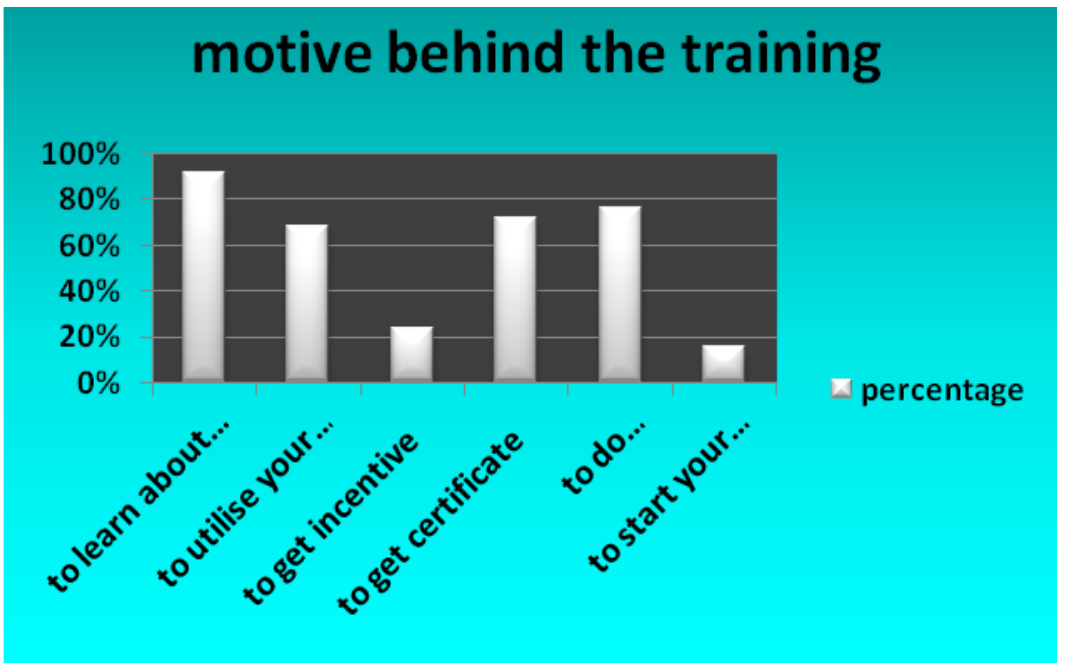

The data presented in Table 4 shows the knowledge gain of different preventive measures to be taken while doing preservation work. 100 percent knowledge gain was observed in counter should be neat and clean whereas 88.00 percent knowledge gain was observed in the abundance availability of fruits and vegetable, product should be kept in clean and dry glass jars/bottles or in earthen pots and in washing of hand. Data further shows 80.00 percent knowledge gain in selection of fruits and vegetables followed by 60.00 percent knowledge gain in the use of apron. The $100 \%$ knowledge gain in counter should be neat and clean shows the impact of the training because hygiene is pre-requisite requirement of any preservative activity. Whereas the least knowledge gains i.e. $64 \%$ in the use of apron was because they don't realise the necessity of apron.
The data furnished in Table 5 reveals the gain in knowledge regarding common preservative products used during preservation. The maximum knowledge gain i.e. 76.00 percent was observed in sugar, sodium benzoate and potassium/sodium meta-bisulphate followed by $68 \% .00$ percent knowledge gain in vinegar and 24.00 percent was observed in salt. The least knowledge gain was in salt, because most of the rural women who do preservative activity at home know that salt act as a preservative.

The data presented in Table 6 reveals the motive of rural women behind the fruit and vegetable preservation training. Maximum number of rural women i.e. 92.00 percent attended the training to learn about food preservation, whereas 76.00 percent of rural women attended training in order to do 
preservation work at home. The table further shows that 72.00 percent rural women attended training to get certificate and 68.00 percent women attended training in order to utilise their time in productive work whereas 24.00 percent rural women are those who were interested only in incentives. The least percentage i.e. $16 \%$ was observed of rural women who were interested to start their own venture. Similar findings are given by Kusum, 2006.

The impact of the training highlights the facts that most of the ladies started preservation work at their home. The study also highlighted the facts that today rural women want to stand up on their own feet but they lack self-confidence and family support. Hence more efforts are to be directed to persuade rural women to start their own cottage industry on preservation. Fruit processing industry is considered to be the sunrise sector of the Indian economy. India has a strong potential for production, consumption and exports. Citrus, Banana, mango, guava, grapes, pineapple and apple are the major varieties grown in India. Favourable agro-climatic conditions make India a potential producer of fruits. Due to inadequate cold chain facilities, logistics infrastructure and post- harvest handling activities, the fruit processing industry is still in its infant stage. Lack of Capacity building initiatives at the farmers, processors and exporters' levels has also contributed towards this effort. Apart from this high competition from global markets and fast obsolescence of technology are the two crucial threats which need to be answered today.

\section{References}

Batra, P. (2011) Feasibility of fruits and Vegetable processing as an enterprise for rural women. M.SC. Thesis. Dept. of Ext. Edu., CCSHAU, Hisar

Kusum (2006) Capacity building of farm women through agri- business activities. M.Sc. Thesis. Dept. of Ext. Edu., CCSHAU, Hisar

Monika Yadav and Shashi Kanta Varma (2014) Capacity building of rural women through processing of fruits and vegetable. Paper presented in National seminar on Life Skill Education for Youth and Development: Challenges and Prospectus, Feb. 12, Organised by Government College for Girls, Panchkula.

\section{How to cite this article:}

Poonam Kundu, Kanta Sabarwal and Sube Singh. 2018. Enhance Food Security through Fruit and Vegetable Preservation. Int.J.Curr.Microbiol.App.Sci. 7(04): 3195-3201. doi: https://doi.org/10.20546/ijcmas.2018.704.362 